\title{
PENGARUH SUKU BUNGA DEPOSITO, NILAI TUKAR DAN INFLASI TERHADAP HARGA OBLIGASI PEMERINTAH YANG TERDAFTAR DI BURSA EFEK INDONESIA PERIODE 2011-2017
}

\author{
Desi Nitasari \\ Program Studi Manajemen \\ Fakultas Ekonomi Universitas Pancasakti
}

\begin{abstract}
The purpose of this study is to 1). To know the effect of deposit interest rate on government bond price, 2). To know the effect of exchange rate on the price of government bonds, 3) To know the effect of inflation on the price of government bonds, 4). To know the effect of deposit interest rate, exchange rate, and inflation simultaneously to government bonds. The method used in this study is multiple regression. While the data analysis methods used are classical assumption test, simple linear regression analysis, test of simple linear regression coefficient, multiple linear regression analysis, multiple linear regression coefficient test, coefficient of determination analysis. Based on the results of simple regression analysis analysis of deposit interest rates on government bond prices obtained sig value. amounted to $0.342>0.05$, so it can be concluded that there is no effect of deposit rates on the price of government bonds listed on the Indonesia Stock Exchange period 2011-2017. From the results of simple regression analysis of the exchange rate against the price of government bonds obtained sig value. amounted to 0.060>0.05, so it can be concluded that there is no effect of exchange rate on the price of government bonds listed on the Indonesia Stock Exchange period 2011-2017. From the results of simple regression analysis of inflation analysis on the price of government bonds obtained sig value. amounted to $0.046<0.05$, so it can be concluded that there is inflationary influence on the price of government bonds listed on the Indonesia Stock Exchange period 2011 2017. From the results of simultaneous testing known significance value of 0.047. Because the probability value of sig nificance of 0,047 <0,05 can be interpreted that there is influence of deposit interest rate, exchange rate, and inflation simultaneously to government bond price listed in Bursa Efek Indonesia period 2011-2017.
\end{abstract}

Keywords: Deposit Interest Rate, Exchange Rate, Inflation, Government Bond Price.

\section{PENDAHULUAN}

\section{Latar Belakang Masalah}

Perkembangan obligasi di Indonesia pada saat ini mulai menunjukkan peningkatan yang cukup tinggi pada saat ini. Dimana obligasi bisa di sebut sebagai alat investasi. Investasi dapat di jadikan alternatif dalam usaha mendapatkan keuntungan yaitu dengan cara menanamkan modal atau dana dengan perolehan di masa datang atau masa depan. Salah satu sarana investasi yang dapat dipilih oleh seorang investor adalah berinvestasi di pasar keuangan (financial market). Pasar modal merupakan salah satu instrumen ekonomi yang mengalami perkembangan yang sangat pesat. Pasar 
modal merupakan indikator kemajuan perekonomian suatu negara serta menunjang ekonomi negara yang bersangkutan. Pasar modal memberikan banyak keuntungan bagi perekonomian suatu negara, yaitu menaikan produktivitas, memperluas lapangan kerja, mencegah terjadinya pengelompokan kapital dan sebagai sumber potensial penerimaan pajak.

Perkembangan pasar modal yang pesat memiliki peran penting dalam meningkatkan pertumbuhan perekonomian, karena pasar modal memiliki dua fungsi, yaitu fungsi ekonomi dan fungsi keuangan. Dalam melaksanakan fungsi ekonomi, pasar modal menyediakan fasilitas untuk memindahkan dana dari pihak yang surplus dana kepada pihak yang membutuhkan dana. Sementara dalam melaksanakan fungsi keuangan, Pasar modal menyediakan dana yang dibutuhkan oleh pihak yang memerlukan dana, dan pihak yang memiliki kelebihan dana dapat ikut terlibat dalam kepemilikan perusahaan. Melalui pasar modal, perusahaan go public bisa memperjual belikan surat berharga setelah terlebih dahulu perusahaan tersebut melakukan penawaran umum sahamnya kepada masyarakat. Di Indonesia perdagangan instrumen pasar modal terdapat di Bursa Efek Indonesia (BEI). Bursa Efek Indonesia sendiri merupakan penggabungan dari Bursa Efek Jakarta dan Bursa Efek Surabaya. Dalam pasar modal terdapat instrumen yang diperdangangkan. Yang dimaksud dengan instrumen pasar modal adalah semua jenis surat berharga (securities) yang diperdagangkan di pasar modal. Jenisjenis surat berharga yang diperdagangkan dipasar modal Indonesia terdiri dari surat berharga yang bersifat ekuitas, surat berharga yang bersifat utang, surat berharga derivatif, dan surat berharga berupa reksa dana.
Perusahaan yang sedang membutuhkan dana untuk ekspansi bisnis mulai melihat obligasi sebagai salah satu alternatif penggalangan dana. Salah satu alasan penerbitan obligasi juga dikarenakan obligasi lebih mudah dan fleksibel dibandingkan dengan prosedur peminjaman di bank. Obligasi ini mempunyai jenis tingkat suku bunga yang tetap (fixed rate) dan suku bunga mengambang (variable rate). Juga waktu jatuh tempo dan nilai nominalnya berbeda tiap serinya. Hal ini memerlukan penanganan pengelolaan obligasi serta dukungan dasar hukum yang kuat. Tanpa adanya penanganan pengelolaan yang profesional, dikhawatirkan akan mengganggu posisi pengeluaran APBN setiap tahunnya. Oleh karena itu, pemerintah mendirikan PMON (Pusat Manajemen Obligasi Negara) di bawah Kementerian Keuangan untuk melakukan pengelolaan obligasi atau surat utang negara.

Selain perusahaan atau korporasi, penerbit obligasi juga di lakukan oleh pemerintah. Pada awalnya obligasi pemerintah di terbitkan untuk menutup defisit APBN dan membiayai dan program restrukturisasi perbankan. Pemerintah pada awalnya menempatkan penyertaan modal dalam bentuk saham pada bank tersebut dengan menggunakan obligasi pemerintah, sehingga neraca bank menjadi lebih baik karena peningkatan asset dalam bentuk obligasi. Kehadiran obligasi pemerintah merupakan bentuk instrument utang pemerintah untuk menyerap dana di pasar dosmetik.

Instrumen obligasi mulai marak dijual dan diperdagangkan di Indonesia. Pemerintah Indonesia telah beberapa kali menerbitkan obligasi pemerintah yang sampai saat ini masih mendapatkan perhatian yang cukup besar dari para investor. Respon yang cukup baik dari para investor ini merupakan perwujudan dari kepercayaan masyarakat terhadap 
kemampuan pemerintah dalam membayar dan melunasi kewajiban-kewajibannya.

Obligasi pemerintah dipilih karena dipandang memiliki risiko investasi yang lebih rendah jika dibandingkan dengan obligasi korporasi. Dengan demikian hampir sebagian besar investor lebih memilih untuk menjadikan obligasi pemerintah sebagai salah satu komponen asset-nya. Berbagai pihak yang berperan sebagai investor atas obligasi pemerintah berinvestasi guna memperoleh pendapatan bunga (interest income) dan keuntungan dari selisih harga beli-jual obligasi (capital gain). Dari seluruh outstanding obligasi pemerintah, kepemilikan oleh pihak non bank terus mengalami peningkatan dari waktu kewaktu.

\section{Pertanyaan Penelitian}

Berdasarkan latar belakang masalah diatas maka dapat dirumuskan masalah sebagai berikut:

Apakah terdapat pengaruh suku bunga deposito terhadap harga obligasi pemerintah yang terdaftar di Bursa Efek Indonesia periode 20112017?

Apakah terdapat pengaruh nilai tukar terhadap harga obligasi pemerintah yang terdaftar di Bursa Efek Indonesia periode 2011-2017?

Apakah terdapat pengaruh inflasi terhadap harga obligasi pemerintah yang terdaftar di Bursa Efek Indonesia periode 2011-2017?

Apakah terdapat pengaruh suku bunga deposito, nilai tukar, dan inflasi secara simultan terhadap harga obligasi pemerintah yang terdaftar di Bursa Efek Indonesia periode 2011-2017?

\section{Tujuan Penelitian}

Berdasarkan latar belakangan rumusan masalah diatas, maka tujuan yang ingin dicapai dalam penelitian ini adalah sebagai berikut:
Untuk mengetahui pengaruh suku bunga deposito terhadap harga obligasi pemerintah yang terdaftar di Bursa Efek Indonesia periode 2011-2017.

Untuk mengetahui pengaruh nilai tukar terhadap harga obligasi pemerintah yang terdaftar di Bursa Efek Indonesia periode 2011-2017.

Untuk mengetahui pengaruh inflasi terhadap harga obligasi pemerintah yang terdaftar di Bursa Efek Indonesia periode 2011-2017.

Untuk mengetahui pengaruh suku bunga deposito, nilai tukar, dan inflasi secara simultan terhadap obligasi pemerintah yang terdaftar di Bursa Efek Indonesia periode 2011-2017.

\section{KERANGKA PEMIKIRAN DAN HIPOTESIS}

Kerangka Pemikiran

Kerangka pemikiran merupakan fondasi dimana seluruh proyek penelitian didasarkan. Kerangka teritis mengelaborasi hubungan antar variabel, menjelaskan teori yang menggaris bawahi relasi tersebut, dan menjelaskan sifat dan arah hubungan (Sekaran, 2011:128).

Penelitian ini dilakukan untuk memperoleh faktor-faktor yang berpengaruh Suku Bunga Deposito terhadap Harga Obligasi Pemerintah Suku bunga deposito menunjukkan apabila suku bunga lebih tinggi maka investor akan lebih memilih menempatkan dananya di deposito dari pada membeli obligasi pemerintah. Dan sebaliknya apabila suku bunga deposito turun, para investor akan membeli obligasi yang mengakibatkan tingginya permintaan dan meningkatknya harga obligasi. Menurut 
Sukanto E (2009) hasilnya menyimpulkan bahwa Bunga deposito berpengaruh signifikan negatif terhadap harga obligasi.

Pengaruh Nilai Tukar terhadap Harga Obligasi Pemerintah Nilai tukar/Kurs apabila kurs rupiah terhadap USD turun maka investasi obligasi meningkat karena nilai tukar mata uang rupiah terhadap beberapa mata uang asing yang belum stabil mempengaruhi jumlah permintaan obligasi.

Pengaruh Inflasi terhadap Harga Obligasi Pemerintah. Menurut Sukanto E (2009) Kurs berpengaruh signifikan negatif terhadap harga obligasi. dan Menurut Azizah Fitriatul (2016) nilai tukar mempunyai pengaruh tidak signifikan terhadap harga obligasi pemerintah.

Inflasi, apabila inflasi naik maka daya beli turun, orang lebih mengutamakan konsumsi daripada investasi turun. Sehingga daya beli terhadap obligasi juga turun. Menurut Sukanto E (2009) Inflasi tidak berpengaruh signifikan terhadap harga obligasi. dan Menurut Azizah Fitriatul (2016) Inflasi tidak berpengaruh signifikan terhadap harga obligasi pemerintah. Menurut Ichsan, Ghazali Syamni, Nurlela dan A.Rahman (2017) inflasi dan nilai tukar rupiah berpengaruh signifikan terhadap nilai obligasi pemerintah.

Berdasarkan penjelasan diatas maka kerangka pemikirannya yang dikemukan sebagai berikut: Harga Obligasi Pemerintah (Y) dipengaruhi oleh Suku Bunga Deposito (X1), Nilai Tukar/Kurs (X2), Inflasi (X3).

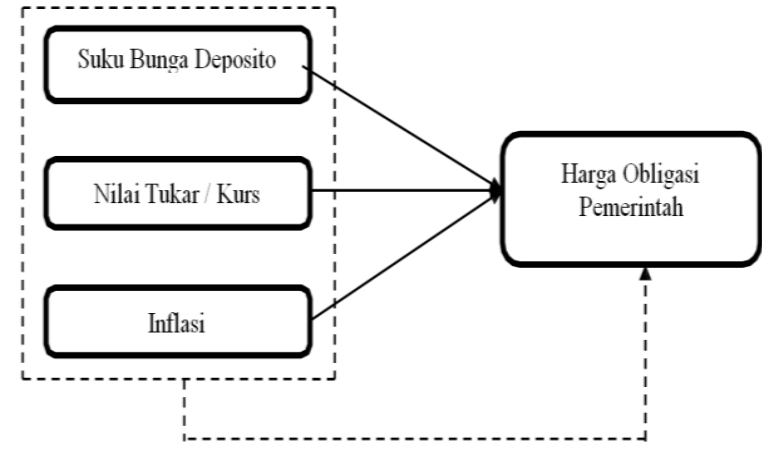

Gambar 1. Kerangka Pemikiran

Keterangan :

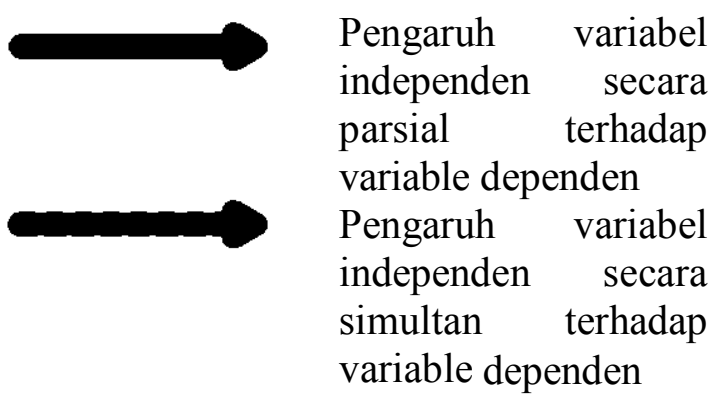

\subsection{Hipotesis}

Maka Hipotesis yang akan diuji dalam penelitian ini adalah :

Terdapat pengaruh suku bunga deposito terhadap harga obligasi pemerintah yang terdaftar di Bursa Efek Indonesia periode 2011-2017.

Terdapat pengaruh nilai tukar terhadap harga obligasi pemerintah yang terdaftar di Bursa Efek Indonesia periode 2011-2017.

Terdapat pengaruh inflasi terhadap harga obligasi pemerintah yang terdaftar di Bursa Efek Indonesia periode 2011-2017.

Terdapat pengaruh suku bunga deposito, nilai tukar dan inflasi secara simultan terhadap harga obligasi pemerintah yang terdaftar di Bursa Efek Indonesia periode 20112017. 
METODE PENELTIAN

\section{Populasi Dan Sampel}

Populasi merupakan jumlah dari keseluruhan objek (satuan-satuan/ individu-individu) yang karakteristiknya hendak diduga (Subagyo dan Djarwanto
2009:93). Populasi penelitian ini adalah seluruh obligasi pemerintah jenis fixed rate selama periode 2011-2017 yang terdaftar di Bursa Efek Indonesia yang berjumlah 40 obligasi pemerintah. Populasinya sebagai berikut :

Tabel 1

Populasi Penelitian

\begin{tabular}{|c|c|c|c|c|}
\hline No & Jenis & Kupon \% & First Issued Date & Maturity Date \\
\hline 1 & FR0031 & 11,000 & 16 Juni 2005 & 15 November 2020 \\
\hline 2 & FR0032 & 15,000 & 1 September 2005 & 15 Juli 2018 \\
\hline 3 & FR0034 & 12,800 & 26 Januari 2006 & 15 Juni 2021 \\
\hline 4 & FR0035 & 12,900 & 16 Februari 2006 & 15 Juni 2022 \\
\hline 5 & FR0036 & 11,500 & 20 April 2006 & 15 September 2019 \\
\hline 6 & FR0037 & 12,000 & 18 Mei 2006 & 15 September 2026 \\
\hline 7 & FR0038 & 11,600 & 24 Agustus 2006 & 15 Agustus 2018 \\
\hline 8 & FR0039 & 11,750 & 24 Agustus 2006 & 15 Agustus 2023 \\
\hline 9 & FR0040 & 11,000 & 21 September 2006 & 15 September 2025 \\
\hline 10 & FR0042 & 10,250 & 25 Januari 2007 & 15 Juli 2027 \\
\hline 11 & FR0043 & 10,250 & 22 Februari 2007 & 15 Juli 2022 \\
\hline 12 & FR0044 & 10,000 & 19 April 2007 & 15 September 2024 \\
\hline 13 & FR0045 & 9,750 & 24 Mei 2007 & 15 Mei 2037 \\
\hline 14 & FR0046 & 9,500 & 19 Juli 2007 & 15 Juli 2023 \\
\hline 16 & FR0048 & 9,000 & 27 September 2007 & 15 September 2018 \\
\hline 17 & FR0050 & 10,500 & 24 Januari 2008 & 15 Juli 2038 \\
\hline 18 & FR0052 & 10,500 & 20 Agustus 2009 & 15 Agustus 2030 \\
\hline 19 & FR0053 & 8,250 & 8 Juli 2010 & 15 Juli 2021 \\
\hline 20 & FR0054 & 9,500 & 15 Juni 2011 & 15 Juli 2031 \\
\hline 21 & FR0056 & 8,375 & 15 Maret 2011 & 15 September 2026 \\
\hline 22 & FR0057 & 9,500 & 15 Mei 2011 & 15 Mei 2041 \\
\hline 23 & FR0058 & 8,250 & 22 Januari 2012 & 15 Juni 2032 \\
\hline 24 & FR0059 & 7,000 & 15 November 2011 & 15 Mei 2027 \\
\hline 25 & FR0061 & 7,000 & 15 Januari 2012 & 15 Mei 2022 \\
\hline 26 & FR0062 & 6,375 & 15 April 2012 & 15 April 2042 \\
\hline 27 & FR0063 & 5,625 & 15 November 2012 & 15 Mei 2023 \\
\hline 28 & FR0064 & 6,125 & 15 November 2012 & 15 Mei 2033 \\
\hline 29 & FR0065 & 6,625 & 15 November 2012 & 15 Mei 2033 \\
\hline 30 & FR0066 & 5,250 & 15 November 2012 & 15 Mei 2018 \\
\hline 31 & FR0067 & 8,750 & 15 Agustus 2013 & 15 Februari 2044 \\
\hline 32 & FR0068 & 8,375 & 15 September 2013 & 15 Maret 2034 \\
\hline 33 & FR0069 & 7,875 & 15 Oktober 2013 & 15 April 2019 \\
\hline 34 & FR0070 & 8,375 & 15 September 2013 & 15 Maret 2024 \\
\hline 35 & FR0071 & 9,000 & 15 September 2013 & 15 Maret 2029 \\
\hline 36 & FR0072 & 8,250 & 15 November 2015 & 15 Mei 2036 \\
\hline 37 & FR0073 & 8,750 & 15 November 2015 & 15 Mei 2031 \\
\hline 38 & FR0074 & 7,500 & 15 November 2017 & 15 Agustus 2032 \\
\hline 39 & FR0075 & 7,500 & 15 November 2017 & 15 Mei 2038 \\
\hline 40 & FR0076 & 7,375 & 22 September 2017 & 15 Mei 2048 \\
\hline
\end{tabular}


Sampel merupakan bagian kecil yang digunakan untuk menunjukkan sifat suatu kelompok yang lebih besar, atau bagian kecil yang mewakili kelompok/keseluruhan yang lebih besar. Menurut Subagyo dan Djarwanto (2009:93). Sampel adalah sebagian dari populasi yang karakteristiknya hendak diselidiki, dan dianggap bisa mewakili keseluruhan populasi (jumlahnya lebih sedikit daripada populasinya).

Sampel adalah bagian dari populasi yang di harapkan mampu mewakili populasi dalam penelitian. Pemilihan sampel dilakukan dengan metode purposive sampling, dimana populasi yang akan di jadikan sampel penelitian merupakan populasi yang memenuhi kriteria sampel tertentu sesuai dengan yang dikehendaki oleh peneliti dan di sesuaikan dengan tujuan penelitian. Dengan pertimbangan arah dan tujuan penelitian, kriteria yang ditetapkan adalah sebagai berikut:

Obligasi pemerintah seri FR (Fixed Rate) dalam mata uang rupiah yang terdaftar di Bursa Efek Indonesia mulai tahun 2011 hingga tahun 2017.

Obligasi pemerintah seri FR yang diterbitkan adalah obligasi yang masih aktif diperdagangkan mulai tahun 2011 hingga tahun 2017.

Dari kriteria diatas diperoleh 18 jenis obligasi pemerintah fixed rate selama periode 2011-2017.

\begin{tabular}{|c|c|c|c|c|}
\hline No & Jenis & Kupon \% & First Issued Date & Maturity Date \\
\hline 1. & FR0057 & 9,500 & 15 Mei 2011 & 15 Mei 2041 \\
\hline 2. & FR0058 & 8,250 & 22 Januari 2012 & 15 Juni 2032 \\
\hline 3. & FR0059 & 7,000 & 15 November 2011 & 15 Mei 2027 \\
\hline 4. & FR0061 & 7,000 & 15 Januari 2012 & 15 Mei 2022 \\
\hline 5. & FR0062 & 6,375 & 15 April 2012 & 15 April 2042 \\
\hline 6. & FR0063 & 5,625 & 15 November 2012 & 15 Mei 2023 \\
\hline 7. & FR0064 & 6,125 & 15 November 2012 & 15 Mei 2033 \\
\hline 8. & FR0065 & 6,625 & 15 November 2012 & 15 Mei 2033 \\
\hline 9. & FR0066 & 5,250 & 15 November 2012 & 15 Mei 2018 \\
\hline 10. & FR0068 & 8,375 & 15 September 2013 & 15 Maret 2034 \\
\hline 11. & FR0069 & 7,875 & 15 Oktober 2013 & 15 April 2019 \\
\hline 12. & FR0070 & 8,375 & 15 September 2013 & 15 Maret 2024 \\
\hline 13. & FR0071 & 9,000 & 15 September 2013 & 15 Maret 2029 \\
\hline 14. & FR0072 & 8,250 & 15 November 2015 & 15 Mei 2036 \\
\hline 15. & FR0073 & 8,750 & 15 November 2015 & 15 Mei 2031 \\
\hline 16. & FR0074 & 7,500 & 15 November 2017 & 15 Agustus 2032 \\
\hline 17. & FR0075 & 7,500 & 15 November 2017 & 15 Mei 2038 \\
\hline
\end{tabular}

Definisi Konseptual Dan

Operasioanl Variabel

Variabel yang digunakan dalam penelitian ini adalah variable dependen dan variable independen.

Variabel Dependen
Harga Obligasi Pemerintah merupakan surat utang yang diterbitkan pemerintah Republik Indonesia dengan jangka waktu lebih dari 12 bulan dengan kupon atau dengan pembayaran bunga secara diskonto yang indikatornya adalah jenis/seri obligasi, tingkat kupon, nilai nominal, waktu penerbitan, dan jatuh 
tempo. Data yang digunakan pada penelitian ini adalah Harga obligasi pemerintah adalah harga obligasi yang tercantum di bursa dan diperjual belikan dari Bursa Efek Indonesia.

Variabel Independen

\section{Suku bunga deposito}

Suku bunga deposito merupakan nilai yang harus diberikan oleh pihak bank kepada nasabah sebagai imbalan atas simpanan nasabah saat ini yang akan dikembalikan bank pada kemudian hari. Data yang digunakan dalam penelitian ini adalah data rata-rata suku bunga deposito 6 bulanan bank umum.
Nilai Tukar/Kurs

Nilai tukar/kurs merupakan harga atau nilai tukar mata uang lokal terhadap mata uang asing. Data kurs yang digunakan untuk penelitian ini adalah kurs tengah rupiah terhadap dollar Amerika Serikat yang dikeluarkan oleh Bank Indonesia. Data kurs diambil dari www.bi.go.id.

Inflasi

Inflasi adalah kecenderungan dari harga-harga untuk naik secara terus menerus. Data yang digunakan pada penelitian ini adalah laporan inflasi oleh Bank Indonesia tiap akhir bulan.

Tabel 3 Definisi Konseptual DanOperasional Variabel

\begin{tabular}{|l|c|l|}
\hline Variabel & Ukuran & \multicolumn{1}{c|}{ Keterangan } \\
\hline $\begin{array}{l}\text { Harga Obligasi } \\
\text { Pemerintah }\end{array}$ & Rupiah & $\begin{array}{l}\text { Harga obligasi pemerintah adalah harga obligasi yang } \\
\text { tercantum di bursa dan diperjual belikan dari Bursa } \\
\text { Efek Indonesia. }\end{array}$ \\
\hline $\begin{array}{l}\text { Suku Bunga } \\
\text { Deposito }\end{array}$ & Prosentase & $\begin{array}{l}\text { Rata-rata tingkat suku bunga deposito berjangka } \\
\text { waktu 6 bulan yang berlaku di Bank umum. }\end{array}$ \\
\hline Nilai Tukar/Kurs & Rupiah & Daftar kurs tengah yang dikeluarkan Bank Indonesia. \\
\hline Inflasi & Prosentase & $\begin{array}{l}\text { Tingkat inflasi yang dikeluarkan oleh Bank Indonesia } \\
\text { tiap akhir bulan. }\end{array}$ \\
\hline
\end{tabular}

\section{Teknik Pengumpulan Data}

Untuk dapat memperoleh data yang dibutuhkan dalam penelitian ini, maka dilakukan prosedur pengumpulan data sebagai berikut:

Jenis Data

Data yang diperlukan untuk mendukung penelitian ini merupakan data sekunder, yaitu data yang diperoleh secara tidak langsung dari sumber utama (perusahaan) yang dijadikan objek penelitian.

Sumber Data

Sumber data yang diperoleh untuk penelitian ini yaitu diperoleh melalui situs:

www.idx.co.id (homepage Bursa Efek Indonesia) www.bi.go.id (homepage Bank Indonesia) www.ibpa.co.id

\section{Teknik Analisis Data}

Metode analisis data yang digunakan adalah Uji asumsi klasik, analisis regresi linier sederhana, uji signifikansi koefisien regresi linier sederhana, analisis regresi linier berganda, uji signifikansi koefisien regresi linier berganda, analisis koefisien determinasi $\left(\mathrm{R}^{2}\right)$.

\section{Uji Asumsi Klasik}

Uji Normalitas

Uji normalitas bertujuan untuk menguji apakah dalam model regresi, variable pengganggu atau residual memiliki distribusi normal. Seperti diketahui bahwa uji $\mathrm{F}$ dan uji $\mathrm{T}$ mengasumsikan jika nilai residual 
mengikuti distribusi normal. Kalau asumsi ini dilanggar maka uji stastistik menjadi tidak valid (Ghozali, 2011:160). Uji normalitas dapat dideteksi dengan melihat penyebaran data (ttik) pada sumbu diagonal dari grafik atau dengan melihat histogram dari residualnya. Dasar pengambilan keputusan :

Jika data menyebar disekitar garis diagonal dan mengikuti garis diagonal atau grafik histogramnya menunjukan pola distribusi normal, maka model regresi memenuhi asumsi normalitas.

Jika data menyebar jauh dari diagonal dan/atau tidak mengikuti arah garis diagonal atau grafik histogram tidak menunjukan pola distribusi normal, maka model regresi tidak memenuhi asumsi klasik.

\section{Uji Multikolonieritas}

Uji Multikolonieritas bertujuan untuk menguji apakah model regresi ditemukan adanya korelasi antar variable bebas (independen). Untuk mendeteksi ada atau tidaknya multikolonieritas didalam model regresi adalah sebagai berikut:

Nilai Ryang dihasilkan oleh suatu estimasi model regresi empiris sangat tinggi, tetapi secara individual variablevariabel independen banyak yang tidak signifikan mempengaruhi variable dependen.

Menganalisis matrik korelasi variable-variabel independen. Jika antara variable independen ada korelasi yang cukup tinggi (umumnya diatas 0,90 ), maka hal ini merupakan indikasi adanya multikolonieritas.Multikolonieritas dapat disebabkan karena adanya efek kombinasi dua variable atau lebih variable independen.
Multikolonieritas dapat juga dilihat dari nilai tolerance dan lawannya variance inflation factor (VIF). Tolerance mengukur variabilitas variable independen yang dipilih yang tidak dijelaskan oleh variable independen lainnya. Jadi, nilai tolerance yang rendah sama dengan nilai VIF tinggi (karena $\mathrm{VIF}=1 /$ Tolerance). Nilai cutoff yang umum dipakai untuk menunjukan adanya multikolonieritas adalah nilai Tolerance $\leq$ 0,10 atau sama dengan nilai VIF $\geq 10$. Nilai Tolerance $=0,10$ sama dengan tingkat kolonieritas 0,95 .

Uji Heteroskedastisitas

Uji Heteroskedastisitas bertujuan menguji apakah dalam model regresi terjadi ketidaksamaan varian dari residual satu pengamatan ke pengamatan yang lain. Jika varian dari residual satu pengamatan ke pengamatan lain tetap, maka disebut Homoskedastisitas dan jika berbeda disebut Heteroskedastisitas. Model regresi yang baik adalah yang Homoskedastisitas atau tidak terjadi Heteroskedastisitas.

Uji Autokorelasi

Uji Autokorelasi bertujuan menguji apakah dalam regresi linier ada korelasi antara kesalahan pengganggu pada periode $\mathrm{t}$ dengan kesalahan pengganggu pada periode t-1 (sebelumnya). Jika terjadi korelasi maka dinamakan ada problem autokorelasi. Autokorelasi muncul karena observasi yang berurutan sepanjang waktu berkaitan satu sama lainnya. Model regresi yang baik adalah regresi yang bebas dari autokorelasi. Dengan menggunakan uji Durbin Watson (DW Test) yaitu uji yang hanya digunakan untuk autokorelasi tingkat satu dan mensyaratkan 
adanya intercept (konstanta) dalam model regresi dan tidak ada variable lag diantara variable independen. Hipotesis yang akan diuji adalah:
H0 : Tidak ada autokorelasi $(\mathrm{r}=0)$

HA : Ada autokorelasi ( $\mathrm{r} \neq 0$ )

Pengambilan keputusan ada tidaknya autokorelasi adalah:

Tabel 4

\begin{tabular}{|l|l|l|}
\hline Hipotesis nol & Keputusan & Jika \\
\hline Tidak ada autokorelasi positif & Tolak & $0<\mathrm{d}<\mathrm{dl}$ \\
$\begin{array}{l}\text { Tidak ada autokorelasi } \\
\text { positif Tidak ada korelasi } \\
\text { negative Tidak ada korelasi } \\
\text { negative }\end{array}$ & No decision & $\mathrm{dl} \leq \mathrm{d} \leq \mathrm{du}$ \\
$\begin{array}{l}\text { Tidak ada autokorelasi, positif } \\
\text { dan negative }\end{array}$ & Tolak & $4-\mathrm{du}<\mathrm{d}<4$ \\
\hline
\end{tabular}

\section{Analisis Regresi Linier Sederhana}

Regresi linear sederhana adalah regresi liner dimana variabel yang terlibat didalamnya hanya dua, yaitu satu variabel terikat $(\mathrm{Y})$ dan satu variabel bebas (X) dan berpangkat satu. Analisis regresi linier sederhana ini digunakan untuk hipotesi satu, dua, tiga dan empat. Persamaan umum regresi linier sederhana adalah:

$$
Y=a+b X+e
$$

Keterangan :

$\mathrm{Y}=$ Subyek dalam variabel dependen yang diprediksikan.

$\mathrm{X}=$ Subyek pada variabel independen yang mempunyai nilai tertentu.

$\mathrm{a}=$ Harga $\mathrm{Y}$ bila $\mathrm{X}=0$ (harga konstan)

$\mathrm{b}=$ Angka arah atau koefisien regresi, yang menunjukkan angka peningkatan ataupun penurunan variabel dependen yang didasarkan perubahan variable independen.

$\mathrm{e}=$ Standard error.
Untuk melihat bentuk korelasi antar variabel dengan persamaan regresi terseut, maka nilai a dan $b$ harus ditentukan terlebih dahulu.

$$
a=\frac{\Sigma Y-b \cdot \Sigma X}{n}
$$

$$
b=\frac{\mathrm{n} \sum \mathrm{XY}-\left(\sum \mathrm{X}\right)-\left(\sum \mathrm{Y}\right)}{\mathrm{n} \sum \mathrm{X} 2-\left(\sum \mathrm{X} 2\right)}
$$

Uji Signifikansi Koefisien Regresi

\section{Linier Sederhana}

Pengujian ini dilakukan untuk menentukan signifikan atau tidak signifikan masing-masing nilai koefisien regresi secara sendiri-sendiri terhadap variabel terikat (Y), langkah pengujiannya adalah:

Menentukan Ho dan Ha :

Formulasi hipotesis 1

Ho : $\beta 1=0$, Tidak terdapat pengaruh yang signifikan suku bunga deposito terhadap 
harga obligasi pemerintah yang terdaftar di Bursa Efek Indonesia periode 2011-2017.

Ho : $\beta 1 \neq 0$, Terdapat pengaruh yang signifikan suku bunga deposito terhadap harga obligasi pemerintah yang terdaftar di Bursa Efek Indonesia periode 2011-2017.

Formulasi hipotesis 2

Ho : $\beta 2=0$, Tidak terdapat pengaruh yang signifikan nilai tukar terhadap harga obligasi pemerintah yang terdaftar di Bursa Efek Indonesia periode 2011-2017.

Ho : $\beta 2 \neq 0$, Terdapat pengaruh yang signifikan nilai tukar terhadap harga obligasi pemerintah yang terdaftar di Bursa Efek Indonesia periode 2011-2017.

Formulasi hipotesis 3

Ho : $\beta 3=0$, Tidak terdapat pengaruh yang signifikan inflasi terhadap harga obligasi pemerintah yang terdaftar di Bursa Efek Indonesia periode 2011-2017.

Ho : $\beta 3 \neq 0$, Terdapat pengaruh yang signifikan inflasi terhadap harga obligasi pemerintah yang terdaftar di Bursa Efek Indonesia periode 2011-2017.

Menentukan Level of Significance $(\alpha)$

Menentukan level signifikansi yaitu sebesar 5\%

Kriteria Pengujian

Ho diterima apabila $=-\mathrm{t}$ tabel $\leq \mathrm{t}$

hitung $\leq \mathrm{t}$ tabel

Ho ditolak apabila $=-\mathrm{t}$ hitung $<$

$-t$ tabel atau $t$ hitung $>t$ table

Kurva Penerimaan/Penolakan Hipotesis Penelitian

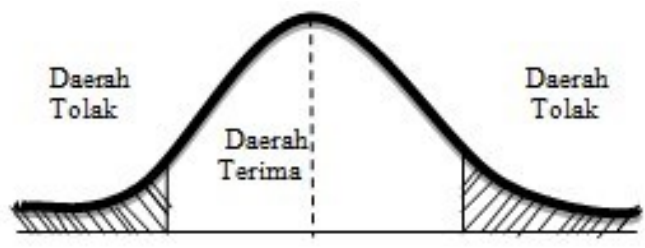

d. Perhitungan nilai $\mathrm{t}$

Menurut Subagyo dan Djarwanto (2011:268)

$$
\begin{aligned}
& S b=\frac{S_{Y X}}{\sqrt{\sum_{t=1}^{n} \frac{X_{i}^{2}-\left(\sum X_{i}^{2}\right)_{t=1}^{n}}{n}}} \\
& S_{Y X}=\sqrt{\frac{\sum Y^{2}-a \cdot \sum Y-b \cdot \sum X Y}{n-2}}
\end{aligned}
$$

Menentukan nilai $t$ hitung dengan formulasi sebagai berikut:

$$
\mathrm{t}_{\text {hitung }}=\frac{b-\beta}{S b}
$$

Pengambilan Kesimpulan, dengan kriteria:

Quick look: apabila jumlah degree of freedom (df) adalah 20 atau lebih, dan derajat kepercayaan sebesar 5\%, maka Ho menyatakan $\mathrm{bi}=0$ dapat ditolak bila nilai t lebih besar dari 2 (dari nilai absolut). Dengan kata lain kita menerima hipotesis alternative, yang menyatakan bahwa suatu variabel independen secara individual mempengaruhi variabel dependen.

Membandingkan nilai statistik $\mathrm{t}$ dengan titik kritis menurut tabel. Apabila nilai statistik $\mathrm{t}$ hasil perhitungan lebih tinggi dibandingkan nilai $\mathrm{t}$ tabel, kita menerima hipotesis alternative yang menyatakan bahwa suatu variabel independen secara individual mempengaruhi variabel dependen. 


\section{Analisis Regresi Linier Berganda}

Analisis regresi linier berganda digunakan oleh peneliti, bila peneliti bermaksud meramalkan bagaimana keadaan (naik turunnya) variabel dependen (kriterium), bila dua atau lebih variabel independen sebagai faktor predictor dimanipulasi (dinaik turunkan nilainya). Jadi analisis regresi linier berganda akan dilakukan bila jumlah variabel independennya minimal 2 (Sugiyono, 2010: 277).

Analisis regresi berganda digunakan untuk memprediksi dan mengetahui pengaruh variabel independen suku bunga deposito, nilai tukar dan inflasi terhadap variabel terikat harga obligasi pemerintah. Persamaan fungsinya dirumuskan sebagai berikut (Sugiyono, 2010: 277):

$$
Y=a+\beta_{1} X_{1}+\beta_{2} X_{2}+\beta_{3} X_{3}+\beta_{4} X_{4}+e
$$

Keterangan :

$\mathrm{Y}=$ harga obligasi pemerintah

$\mathrm{X} 1$ = suku bunga deposito

$\mathrm{X} 2=$ nilai tukar

$\mathrm{X} 3$ = inflasi

$\alpha=$ konstanta

$\beta 1=$ koefisien variable $\mathrm{X} 1$

$\beta 2=$ koefisien variable $\mathrm{X} 2$

$\beta 3=$ koefisien variable $\mathrm{X} 3$

$\mathrm{e} \quad$ gangguan acak

\section{Uji Signifikansi Koefisien Regresi Linier Berganda}

Pengujian terhadap hipotesis yang dilakukan dalam penelitian ini dilakukan dengan menggunakan uji F. Uji statistik $F$ pada dasarnya menunjukkan apakah semua variabel independen atau bebas yang di masukkan dalam model mempunyai pengaruh secara bersamasama terhadap variabel dependen/terikat (Ghozali, 2011: 98). Untuk mengetahui signifikan analisis regresi berganda langkah-langkah sebagai berikut :
Formulasi Hipotesis

Hipotesis statistik yang akan di uji dapat diformulasikan :

Ho : $\beta 1, \beta 2, \beta 3,=0$, : Tidak terdapat pengaruh signifikan antara suku bunga deposito, nilai tukar, dan inflasi secara simultan terhadap harga obligasi pemerintah yang terdaftar di Bursa Efek Indonesia periode 2011-2017.

Ho : $\beta 1, \beta 2, \beta 3, \neq 0,:$ Terdapat pengaruh signifikan suku bunga deposito, nilai tukar, dan inflasi secara simultan terhadap harga obligasi pemerintah yang terdaftar di Bursa Efek Indonesia periode 2011-2017.

Taraf signifikan

Untuk menguji tingkat koefisien korelasi yang diperoleh akan digunakan uji $\mathrm{F}$ pihak kanan dengan tingkat signifikan sebesar 95\% (atau $\alpha=5 \%$ )

\section{Kriteria Pengujian Hipotesis}

Kriteria untuk menerima atau menolak Ho yaitu:

Ho diterima apabila : Fhitung $\leq$

$$
\mathrm{F} \alpha: \mathrm{k}-1: \mathrm{k}(\mathrm{n}-1)
$$

Ho ditolak apabila : Fhitung $>\mathrm{F}_{\alpha}$

$$
: \mathrm{k}-1: \mathrm{k}(\mathrm{n}-1)
$$

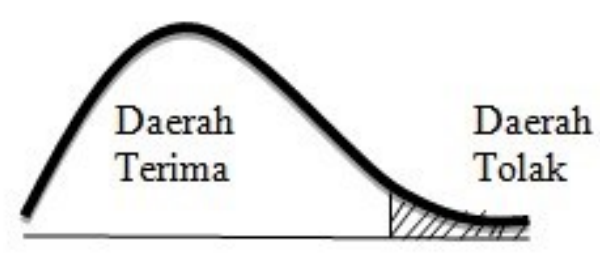

\section{Menghitung F Hitung}

Menggunakan rumus sebagai berikut:

$$
\mathrm{F}_{\text {hitung }}=\frac{J K r e g / k}{J K r e s /(n-k-1)}
$$

Dimana : 
Menghitung jumlah kuadrat X Y dengan rumus:

$$
J K X_{1} Y=\sum X_{1} Y-\frac{\sum X_{1} \cdot \sum Y}{N}
$$

Menghitung jumlah kuadrat total dengan rumus

$$
J K Y=\sum Y^{2}-\frac{\left(\sum Y\right)^{2}}{N}
$$

Menghitung jumlah kuadrat regresi dengan rumus: JKReg $=b$ (JK X1 Y)

Menghitung jumlah kuadrat residu

$$
\begin{aligned}
& \mathrm{JKRes}=\mathrm{JKRes}=\mathrm{JK} \mathrm{Y}-\mathrm{JKreg} \\
& \text { Keterangan : } \\
& \text { Jkreg }=\text { Jumlah Kuadrat Regresi } \\
& \text { Jkres }=\text { Jumlah Kuadrat Residu } \\
& \mathrm{k}=\text { Jumlah Variabel Bebas } \\
& \mathrm{n} \quad=\text { Jumlah Sampel }
\end{aligned}
$$

\section{Analisis Koefisien Determinasi $\left(\boldsymbol{R}^{2}\right)$}

Koefisien Determinasi $\left(\mathrm{R}^{2}\right)$ mengukur seberapa jauh kemampuan model dalam menerangkan variasi variabel dependen. Nilai koefisien determinasi adalah antara nol. Nilai $\mathrm{R}^{2}$ yang kecil berarti kemampuan variabel-variabel independen dalam menjelaskan variasi variabel dependen amat terbatas. Nilai yang mendekati satu berarti variabel variabel independen memberikan hampir semua informasi yang dibutuhkan untuk memprediksi variasi variabel dependen. Secara umum koefisien determinasi untuk data saling (crossection) relative rendah karena adanya variasi yang besar antara masing-masing pengamatan, sedangkan untuk data runtun waktu (time series) biasanya mempunyai nilai koefisien determinasi yang tinggi (Ghozali, 2013: 99).
Dalam kenyataan nilai adjusted $\mathrm{R}^{2}$ dapat bernilai negative, walaupun yang dikehendaki harus bernilai positif. Formulasi untuk menghitung besarnya koefisien determinasi adalah sebagai berikut:

$$
J R 2=1-\frac{\sum(\hat{Y} i-\bar{Y})^{2}}{\sum(Y-\bar{Y})^{2}}
$$

Menurut Gujarati (2003) dalam Ghozali (2011:97) jika dalam uji empiris didapat nilai adjusted $\mathrm{R}^{2}$ negatif, maka nilai adjusted $\mathrm{R}^{2}$ dianggap bernilai 0 .

Jika nilai $\mathrm{R} 2=1$, maka Adjusted $\mathrm{R} 2=$ $\mathrm{R} 2=1$.

Jika nilai $\mathrm{R} 2=0$, maka adjusted $\mathrm{R} 2$ $(1-\mathrm{k}) /(\mathrm{n}-\mathrm{k})$. Jika $\mathrm{k}>1$, maka adjusted R2 akan bernilai negatif. Nilai koefisien determinasi terletak pada:

$$
0 \leq \mathrm{R}^{2} \leq 1
$$

Semakin angkanya mendekati 1 maka semakin baik garis regresi karena mampu menjelaskan data aktualnya. Semakin mendekati angka nol maka garis regresinya kurang baik. Dapat dikatakan bahwa sebuah garis regresi adalah baik jika nilai $\mathrm{R}^{2}$ tinggi dan sebaliknya bila $\mathrm{R}^{2}$ rendah maka mempunyai garis regresi yang kurang baik.

\section{ANALISIS DATA DAN UJI HIPOTESIS}

\section{Uji Asumsi Klasik}

Model regresi linier berganda (multiple regression) dapat disebut sebagai model yang baik jika model tersebut memenuhi kriteria BLUE (Best Linear Unbiased Estimator). Model regresi yang baik adalah bebas dari asumsi klasik yang terdiri dari uji multikolinearitas, uji heteroskedastisitas, 
dan uji autokorelasi, serta memiliki distribusi data normal atau mendekati normal. Data yang berhasil dikumpulkan, sebelum dilakukan analisis terlebih dahulu dilakukan pengujian terhadap penyimpangan asumsi klasik dengan tahapan sebagai berikut :

Uji Normalitas data

Uji normalitas bertujuan untuk menguji apakah dalam model regresi, variabel pengganggu atau residual memiliki distribusi normal. Dalam uji normalitas ini ada 2 cara untuk mendeteksi apakah residual berdistribusi normal atau tidak, yaitu dengan analisis grafik dan analisis statistik.

Proses uji normalitas data dilakukan dengan memperhatikan penyebaran data (titik- titik) pada normal P-Plot of Regresion Standardized Residual dari variabel independen dimana :

Jika data menyebar disekitar garis diagonal dan mengikuti arah garis diagonal maka model regresi memenuhi asumsi normalitas.

Jika data menyebar jauh dari garis diagonal dan atau tidak mengikuti garis diagonal maka model regresi tidak memenuhi asumsi normalitas.

Berikut ini adalah hasil pengujian normalitas dengan menggunakan normal P-plot of regresion standardized residual dalam penelitian ini :

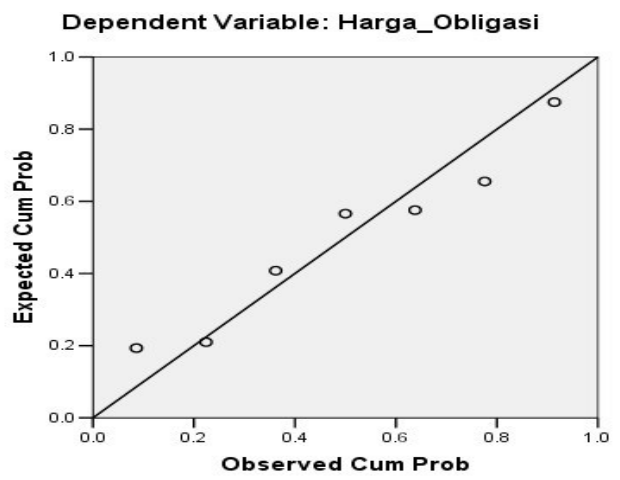

Gambar 2. Hasil Uji Normlaitas
Berdasarkan hasil dari uji normalitas pada penelitian ini dapat dilihat bahwa titik-titik menyebar disekitar garis diagonal dan penyebaran mengikuti arah garis diagonal. Dengan demikian dapat dinyatakan bahwa penyebaran data mendekati normal atau memenuhi asumsi normalitas.

Uji statistik lain yang dapat digunakan untuk menguji normalitas residual adalah uji statistik nonparametik Kolmogorov-Smirnov (K$\mathrm{S})$. Uji K-S dilakukan dengan membuat hipotesis (Ghozali, 2011:140). Adapun penentuan pengujiannya adalah :

Nilai probabilitas $<0,05=$ tolak Ho

Nilai probabilitas $>0,05=$ terima $\mathrm{Ha}$

Model regresi yang baik adalah memiliki distribusi data normal atau mendekati normal. Deteksi normalitas dapat dilakukan dengan melakukan uji sampel KolmogorofSmirnov atau melihat histogram dan residualnya dan melihat persebaran data pada sumbu diagonal atu grafik normal dimana bentuk grafikk mengikuti bentuk lonceng. Bila distribusi normal maka model regresi memenuhi asumsi normalitas. Berikut ini adalah hasil pengujian normalitas dengan menggunakan uji one sample Kolmogorof-Smirnov dalam penelitian ini :

Tabel 5. Hasil uji one sample Kolmogorof-Smirnov

One-Sample Kolmogor ov-Smirnov Test

\begin{tabular}{|c|c|c|}
\hline & & $\begin{array}{l}\text { Unstandardiz } \\
\text { ed Residual }\end{array}$ \\
\hline \multicolumn{2}{|l|}{$\mathrm{N}$} & \\
\hline \multirow[t]{2}{*}{ Normal Parameters $a . b$} & Mean & .0000000 \\
\hline & Std. Dev iation & .13052439 \\
\hline \multirow{3}{*}{$\begin{array}{l}\text { Most Extrem e } \\
\text { Dif f erences }\end{array}$} & Absolute & ,164 \\
\hline & Positiv e & ,159 \\
\hline & Negativ e &,- 164 \\
\hline Kolmogorov-Smirnov Z & &, 434 \\
\hline Asy mp. Sig. (2-tailed) & & 992 \\
\hline
\end{tabular}


Berdasarkan hasil perhitungan diperoleh nilai signifikansi one sample kolmogorov smirnov dengan unstandardized residual diperoleh nilai sebesar 0,992. Perbandingan antara probability dengan standar signifikansi yang sudah ditentukan diketahui bahwa nilai probability lebih besar dari 0,05. Sehingga menunjukkan bahwa distribusi data dalam penelitian ini normal.

\section{Uji Multikolinieritas}

Uji Multikolinearitas bertujuan untuk menguji apakah model regresi ditemukan adanya korelasi antara variabel bebas. Model regresi yang baik seharusnya tidak terjadi korelasi diantara variabel bebas. Untuk mendeteksi ada atau tidaknya multikolinearitas di dalam model regresi dilihat dari hubungan antara variabel bebas yang ditunjukkan oleh angka tolerance dan variance inflation factor (VIF) yaitu :

Tabel 6. Hasil Uji Multikolinieritas

\begin{tabular}{|c|c|c|c|c|c|c|c|c|}
\hline \multicolumn{9}{|c|}{ Coeffi ci ents ${ }^{a}$} \\
\hline \multirow[b]{2}{*}{ Mod } & & \multicolumn{2}{|c|}{$\begin{array}{l}\text { Unstandardized } \\
\text { Coef ficients }\end{array}$} & \multirow{2}{*}{$\begin{array}{c}\text { St andardized } \\
\text { Coef ficients } \\
\text { Beta }\end{array}$} & \multirow[b]{2}{*}{$t$} & \multirow[b]{2}{*}{ Siq. } & \multicolumn{2}{|c|}{ Collinearity Statistics } \\
\hline & & B & St d. Error & & & & Tolerance & VIF \\
\hline \multirow[t]{4}{*}{1} & (Constant) & 83,711 & 4,242 & & 19,735 &, 000 & & \\
\hline & Bunga_Deposit o &,- 124 & 064 &,- 505 & $-1,956$ & 145 & ,414 & 2,414 \\
\hline & Nilai_tukar & 1,497 & ,468 &, 585 & 3,199 &, 049 & ,826 & 1,211 \\
\hline & Inf lasi & ,301 & ,084 & ,921 & 3,600 &, 037 & ,421 & 2,373 \\
\hline
\end{tabular}

a. Dependent Variable: Harga_Obligasi

Dari hasil perhitungan uji asumsi klasik pada bagian collinearity statistic terlihat untuk tiga variabel independen, angka VIF yaitu masing-masing sebesar 2,414; 1,211 dan 2,372 yang lebih kecil dari 10 sehingga tidak melebihi batas nilai VIF yang diperkenankan yaitu maksimal sebesar 10 dan nilai tolerance $>0,10$. Dengan demikian dapat disimpulkan bahwa model regresi tersebut tidak terdapat masalah multikolinearitas.

\section{Uji Heterokedastisitas}

Heteroskedastisitas adalah adanya varians variabel dalam model regresi yang tidak sama (konstan). Pada suatu model regresi yang baik adalah yang berkondisi homokedastisitas atau tidak terjadi heterokedastisitas. Konsekuensi adanya heroskedastisitas dalam model regresi adalah penaksir (estimator) yang diperoleh tidak efisien, baik dalam sampel kecil maupun sampel besar. Salah satu cara untuk mendiagnosis adanya heteroskedastisitas dalam suatu model regresi adalah dengan melihat grafik plot antara nilai prediksi variabel terikat (ZPRED) dengan residualnya (SRESID). Adapun dasar analisis dengan melihat grafik plot adalah sebagai berikut :

Jika terdapat pola tertentu, seperti titik-titik yang ada membentuk pola tertentu yang teratur maka menunjukkan telah terjadi heterokedastisitas

Jika tidak ada pola yang jelas serta titik-titik menyebar di atas dan di bawah angka 0 pada sumbu Y, maka tidak terjadi heterokedastisitas.

Berikut ini adalah hasil pengujian heteroskedastisitas dalam penelitian ini : 


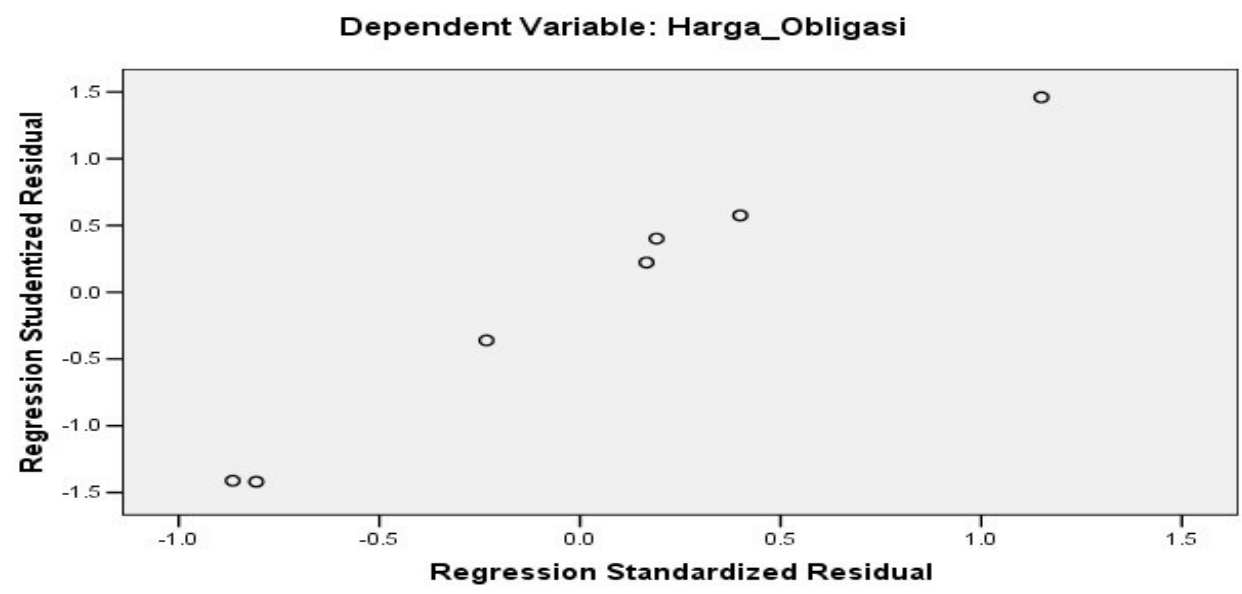

Gambar 3. Hasil Uji Heteroskedastisitas

Berdasarkan grafik scatterplot

tertentu yang teratur dan titiktitik menyebar di atas dan di bawah angka 0 pada sumbu Y. Hal ini berarti tidak terjadi heteroskedastisitas pada model regresi.

\section{Uji Autokorelasi}

Autokorelasi adalah korelasi antara anggota-anggota serangkaian observasi yang tersusun dalam rangkaian waktu atau yang tersusun dalam rangkaian ruang. Konsekuensi dari adanya autokorelasi dalam suatu model regresi adalah varians sampel tidak dapat menggambarkan varians populasinya. Salah satu cara untuk mengetahui ada tidaknya autokorelasi pada model regresi adalah dengan melakukan Uji Durbin Watson (DW). Pengambilan keputusan ada tidaknya korelasi :

Bila nilai Dw terletak antara batas atas atau Upper bound (du) bahwa tidak ditemukan pola dan (4-du), maka koefisien autokorelasi sama dengan nol yang berarti tidak ada gangguan autokorelasi.

Bila nilai Dw lebih rendah dari batas bawah atau Lower Bound sebesar (du), maka koefisien autokorelasi lebih besar dari nol yang berarti ada masalah autokorelasi positif.

Bila nilai Dw lebih besar dari (4dl), maka koefisien autokorelasi lebih kecil daripada nol yang berarti ada autokorelasi ada autokorelasi negative

Bila nilai Dw terletak antara batas atas (du) dan batas bawah (dl), maka hasilnya tidak dapat disimpulkan.

Berikut ini adalah hasil pengujian autokorelasi dalam penelitian ini:

Tabel 7. Hasil Uji Autokorelasi

Model Summar $y^{b}$

\begin{tabular}{|l|r|r|r|r|r|}
\hline Model & $\mathrm{R}$ & $\mathrm{R}$ Square & $\begin{array}{l}\text { Adjusted } \\
\mathrm{R} \text { Square }\end{array}$ & $\begin{array}{l}\text { Std. Error of } \\
\text { the Est im at }\end{array}$ & $\begin{array}{c}\text { Durbin- } \\
\text { Watson }\end{array}$ \\
\hline 1 &, $958^{\mathrm{a}}$ &, 917 &, 834 &, 18459 & 2,052 \\
\hline
\end{tabular}

a. Predictors: (Constant), Inf lasi, Nilai_tukar, Bunga_Deposito

b. Dependent Variable: Harga_Obligasi 
Uji autokorelasi menggunakan pengujian Durbin-Watson. Berdasarkan hasil perhitungan dengan bantuan program SPSS, menunjukan hasil sebesar 2,052. Dengan 3 variabel bebas, dan $\mathrm{n}=7$ diketahui du $=1,8964$, sedangkan 4 $\mathrm{du}(4-1,8964)=2,1036$. Sehingga hasil perhitungan uji durbin watson terletak diantara 1,8964 - 2,1036 yang berarti model regresi tidak ada masalah autokorelasi.

\section{Analisis Regresi Sederhana}

Regresi sederhana digunakan untuk melihat besarnya pengaruh dari variabel bebas terhadap variabel terikat. Berikut ini adalah hasil analisis regresi sederhana dalam penelitian ini:

Analisis Regresi Sederhana Bunga Deposito Terhadap Harga Obligasi Pemerintah

Tabel 8. Hasil Pengujian Analisis Regresi Sederhana Bunga Deposito Terhadap Harga Obligasi Pemerintah

Coeffici ents

\begin{tabular}{|c|c|c|c|c|c|c|}
\hline \multirow{2}{*}{\multicolumn{2}{|c|}{ Model }} & \multicolumn{2}{|c|}{$\begin{array}{l}\text { Unstandardized } \\
\text { Coeff icients }\end{array}$} & \multirow{2}{*}{$\begin{array}{l}\text { Standardized } \\
\text { Coefficients } \\
\text { Beta }\end{array}$} & \multirow[b]{2}{*}{$\mathrm{t}$} & \multirow[b]{2}{*}{ Siq. } \\
\hline & & $\mathrm{B}$ & Std. Error & & & \\
\hline \multirow[t]{2}{*}{1} & (Constant) & 97,689 & ,709 & & 137,838 & ,000 \\
\hline & Bunga_Deposito & , 105 & 100 & , 425 & 1,050 & ,342 \\
\hline
\end{tabular}

a. Dependent Variable: Harga Obligasi

Berdasarkan hasil perhitungan analisis regresi sederhana dengan menggunakan program SPSS diperoleh persamaan regresi yaitu $\hat{Y}$ $=97,689+0,105 \mathrm{X} 1$ dan dapat diambil suatu analisis bahwa :

Nilai a (konstanta) sebesar 97,689 dapat diartikan bahwa jika suku bunga deposito bernilai tetap atau konstan maka harga obligasi pemerintah yang terdaftar di Bursa Efek Indonesia periode 2011-2017 akan bernilai 97,689.

Koefisien regresi untuk suku bunga deposito sebesar 0,105 dan bertanda positif, menyatakan bahwa setiap peningkatan $1 \%$ suku bunga deposito maka akan meningkatkan harga obligasi pemerintah yang terdaftar di Bursa Efek Indonesia periode 2011-2017 sebesar Rp. 0,105.

Dari hasil pengujian signifikansi analisis regresi sederhana suku bunga deposito terhadap harga obligasi pemerintah diperoleh nilai sig. sebesar 0,342>0,05, sehingga dapat disimpulkan bahwa terdapat pengaruh yang tidak signifikan suku bunga deposito terhadap harga obligasi pemerintah yang terdaftar di Bursa Efek Indonesia periode 20112017.

Analisis Regresi Sederhana Nilai Tukar Terhadap Harga Obligasi Pemerintah

Tabel 9. Hasil Pengujian Analisis Regresi Sederhana Nilai Tukar Terhadap Harga Obligasi Pemerintah

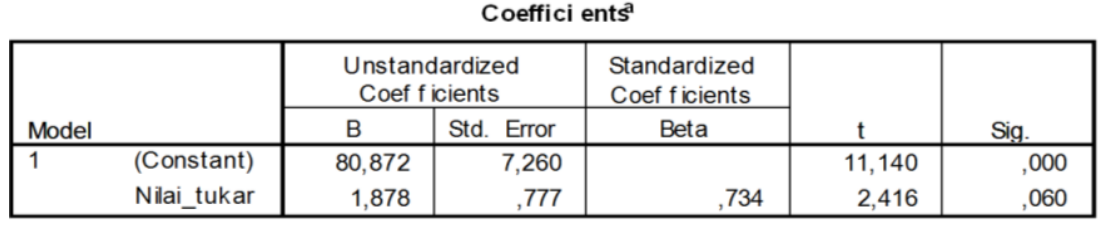

a. Dependent Variable: Harga_Obligasi 
Berdasarkan hasil perhitungan analisis regresi sederhana dengan menggunakan program SPSS diperoleh persamaan regresi yaitu $\hat{Y}$ $=80,872+1,878 \mathrm{X} 2$ dan dapat diambil suatu analisis bahwa :

Nilai a (konstanta) sebesar 80,872 dapat diartikan bahwa jika nilai tukar bernilai tetap atau konstan maka harga obligasi pemerintah yang terdaftar di Bursa Efek Indonesia periode 2011-2017 akan bernilai 80,872.

Koefisien regresi untuk nilai tukar sebesar 1,878 dan bertanda positif, menyatakan bahwa setiap peningkatan $1 \%$ nilai tukar maka akan meningkatkan harga obligasi pemerintah yang terdaftar di Bursa Efek Indonesia periode 2011-2017 sebesar Rp.1,878.

Dari hasil pengujian signifikansi analisis regresi sederhana nilai tukar terhadap harga obligasi pemerintah diperoleh nilai sig. sebesar $0,060>$ 0,05 , sehingga dapat disimpulkan bahwa terdapat pengaruh yang tidak signifikan nilai tukar terhadap harga obligasi pemerintah yang terdaftar di Bursa Efek Indonesia periode 20112017.

c. Analisis Regresi Sederhana Inflasi Terhadap Harga Obligasi Pemerintah

Tabel 10. Hasil Pengujian Analisis Regresi Sederhana Inflasi Terhadap Harga Obligasi Pemerintah

Coeffi ci ents ${ }^{\mathrm{a}}$

\begin{tabular}{|c|c|c|c|c|c|c|}
\hline \multirow{2}{*}{\multicolumn{2}{|c|}{ Model }} & \multicolumn{2}{|c|}{$\begin{array}{l}\text { Unstandardized } \\
\text { Coef f icients }\end{array}$} & \multirow{2}{*}{$\begin{array}{l}\text { St andardized } \\
\text { Coef f icients } \\
\text { Beta }\end{array}$} & \multirow[b]{2}{*}{$\mathrm{t}$} & \multirow[b]{2}{*}{ Siq. } \\
\hline & & B & Std. Error & & & \\
\hline \multirow[t]{2}{*}{1} & (Constant) & 97,103 & ,511 & & 189,893 &, 000 \\
\hline & Inf lasi & ,249 & 095 & ,762 & 2,635 & ,046 \\
\hline
\end{tabular}

a. Dependent Variable: Harga_Obligasi

Berdasarkan hasil perhitungan analisis regresi sederhana dengan menggunakan program SPSS diperoleh persamaan regresi yaitu $\hat{Y}$ $=97,103+0,249 \mathrm{X} 3$ dan dapat diambil suatu analisis bahwa :

Nilai a (konstanta) sebesar 97,103 dapat diartikan bahwa jika inflasi bernilai tetap atau konstan maka harga obligasi pemerintah yang terdaftar di Bursa Efek Indonesia periode 2011-2017 akan bernilai 97,103.

Koefisien regresi untuk inflasi sebesar 0,249 dan bertanda positif, menyatakan bahwa setiap peningkatan $1 \%$ inflasi maka akan meningkatkan harga obligasi pemerintah yang terdaftar di
Bursa Efek Indonesia periode 2011-2017 sebesar Rp. 0,249.

Dari hasil pengujian signifikansi analisis regresi sederhana inflasi terhadap harga obligasi pemerintah diperoleh nilai sig. sebesar $0,046<$ 0,05 , sehingga dapat disimpulkan bahwa terdapat pengaruh yang signifikan inflasi terhadap harga obligasi pemerintah yang terdaftar di Bursa Efek Indonesia periode 20112017.

\section{Analisis Regresi Berganda}

Analisis regresi linear berganda yaitu mengukur kekuatan hubungan antara dua variabel atau lebih, juga menunjukkan arah hubungan antara variabel dependen dengan variabel independent. Teknik estimasi variabel 
dependen yang melandasi analisis regresi disebut Ordinary Least Squares (OLS). Ordinary Least Square (OLS) merupakan salah satu cara untuk menghitung parameter $\alpha, \beta$ dan e dari suatu persamaan regresi.

Tabel 11. Hasil Uji Analisis Regresi Berganda

\begin{tabular}{|c|c|c|c|c|c|c|c|c|}
\hline \multicolumn{9}{|c|}{ Coeffi ci ents ${ }^{a}$} \\
\hline & & \multicolumn{2}{|c|}{$\begin{array}{l}\text { Unstandardized } \\
\text { Coef ficients }\end{array}$} & $\begin{array}{l}\text { St andardized } \\
\text { Coef } f \text { icients }\end{array}$ & \multirow[b]{2}{*}{$t$} & \multirow[b]{2}{*}{ Sig. } & \multicolumn{2}{|c|}{ Collinearity Statistics } \\
\hline \multicolumn{2}{|c|}{ Model } & B & Std. Error & Beta & & & Tolerance & VIF \\
\hline \multirow[t]{4}{*}{1} & (Constant) & 83,711 & 4,242 & & 19,735 &, 000 & & \\
\hline & Bunga_Deposit o &,- 124 &, 064 &,- 505 & $-1,956$ & ,145 & , 414 & 2,414 \\
\hline & Nilai_tukar & 1,497 & , 468 &, 585 & 3,199 & 049 & ,826 & 1,211 \\
\hline & Inf lasi & ,301 & 084 & ,921 & 3,600 & ,037 & 421 & 2,373 \\
\hline
\end{tabular}

a. Dependent Variable: Harga Obligasi

Adapun hasil persamaan regresi dalam penelitian ini untuk menguji hipotesis secara keseluruhan pada penelitian ini adalah sebagai berikut:

$\hat{\mathrm{Y}}: 83,711-0,124 \mathrm{X} 1+1,497 \mathrm{X} 2+$ 0,301X3.

Dari persamaan regresi di atas, dapat diartikan bahwa :

Nilai a (konstanta) sebesar 83,711 dapat diartikan bahwa jika suku bunga deposito, nilai tukar dan inflasi bernilai tetap atau konstan maka harga obligasi pemerintah yang terdaftar di Bursa Efek Indonesia periode 2011-2017 akan bernilai 83,711.

Koefisien regresi untuk suku bunga deposito sebesar 0,124 dan bertanda negatif, menyatakan bahwa setiap peningkatan $1 \%$ suku bunga deposito maka akan menurunkan harga obligasi pemerintah yang terdaftar di Bursa Efek Indonesia periode 2011-2017 sebesar Rp. 0,124.
Koefisien regresi untuk nilai tukar sebesar 1,497 dan bertanda positif, menyatakan bahwa setiap peningkatan $1 \%$ nilai tukar maka akan meningkatkan harga obligasi pemerintah yang terdaftar di Bursa Efek Indonesia periode 2011-2017 sebesar Rp. 1,497.

Koefisien regresi untuk inflasi sebesar 0,301 dan bertanda positif, menyatakan bahwa setiap peningkatan $1 \%$ inflasi maka akan meningkatkan harga obligasi pemerintah yang terdaftar di Bursa Efek Indonesia periode 2011-2017 sebesar Rp. 0,301 .

\section{Uji Simultan}

Uji simultan menunjukkan apakah semua variabel independen yang dimasukkan dalam model mempunyai pengaruh secara simultan terhadap variabel dependen. Berikut ini adalah hasil uji simultan dalam penelitian ini:

ANOVA

\begin{tabular}{|c|c|c|c|c|c|c|}
\hline \multicolumn{2}{|c|}{ Model } & $\begin{array}{l}\text { Sum of } \\
\text { Squares }\end{array}$ & df & Mean Square & $F$ & Sig. \\
\hline 1 & Regression & 1,988 & 3 & ,663 & 9,681 &, $047^{a}$ \\
\hline & Residual & ,205 & 3 & ,068 & & \\
\hline & Total & 2,193 & 6 & & & \\
\hline
\end{tabular}

a. Predictors: (Constant), Inf lasi, Bunga_Deposit o, Nilai_tukar

b. Dependent Variable: Harga_Obligasi 
Dari hasil pengujian simultan di atas diketahui nilai signifikansi sebesar 0,047 . Karena nilai probabilitas signifikansi sebesar $0,047<0,05$ dapat diartikan bahwa ada pengaruh yang signifikan suku bunga deposito, nilai tukar, dan inflasi secara simultan terhadap harga obligasi pemerintah yang terdaftar di Bursa Efek Indonesia periode 2011-2017.

\section{Koefisien Determinasi (R Square)}

Nilai koefisien determinasi $\left(\mathrm{R}^{2}\right)$ menunjukkan persentase pengaruh semua variabel independen (suku bunga deposito, nilai tukar, dan inflasi) terhadap nilai variabel dependen (harga obligasi pemerintah). Koefisien determinasi $\left(\mathrm{R}^{2}\right)$ dapat dicari dengan formulasi : Besarnya koefisien determinasi adalah 0 sampai dengan 1. Semakin mendekati nol, semakin kecil pula pengaruh semua variabel independen $(\mathrm{X})$ terhadap nilai variabel dependen (dengan kata lain semakin kecil kemampuan model dalam menjelaskan perubahan nilai variabel dependen). Sedangkan jika koefisien determinasi mendekati satu, maka sebaliknya.

Model Summar $y^{b}$

\begin{tabular}{|l|r|r|r|r|r|}
\hline Model & $\mathrm{R}$ & R Square & $\begin{array}{c}\text { Adjusted } \\
\text { R Square }\end{array}$ & $\begin{array}{c}\text { Std. Error of } \\
\text { the Est im at e }\end{array}$ & $\begin{array}{c}\text { Durbin- } \\
\text { Watson }\end{array}$ \\
\hline 1 &, $958^{\mathrm{a}}$ &, 917 &, 834 &, 18459 & 2,052 \\
\hline
\end{tabular}

a. Predictors: (Constant), Inf lasi, Nilai_tukar, Bunga_Deposito

b. Dependent Variable: Harga_Obligasi

Dari hasil perhitungan koefisien determinasi dapat diketahui nilai koefisien determinasi sebesar 0,917. Nilai koefisien determinasi sebesar 0,917 tersebut mengandung arti bahwa variabel suku bunga deposito, nilai tukar, dan inflasi secara simultan memberikan pengaruh kepada harga obligasi pemerintah yang terdaftar di Bursa Efek Indonesia periode 20112017 sebesar $91,7 \%$ dan sisanya 8,3\% dipengaruhi oleh variabel lain yang tidak dapat dijelaskan.

\section{KESIMPULAN DAN SARAN}

\section{Kesimpulan}

Berdasarkan hasil penelitian yang telah dilakukan maka dapat diambil beberapa kesimpulan sebagai berikut :

Hasil pengujian analisis regresi sederhana suku bunga deposito terhadap harga obligasi pemerintah diperoleh nilai sig. sebesar $0,342>$
0,05, sehingga dapat disimpulkan bahwa tidak terdapat pengaruh suku bunga deposito terhadap harga obligasi pemerintah yang terdaftar di Bursa Efek Indonesia periode 20112017.

Hasil pengujian analisis regresi sederhana nilai tukar terhadap harga obligasi pemerintah diperoleh nilai sig. sebesar $0,060>0,05$, sehingga dapat disimpulkan bahwa tidak terdapat pengaruh nilai tukar terhadap harga obligasi pemerintah yang terdaftar di Bursa Efek Indonesia periode 2011-2017.

Hasil pengujian analisis regresi sederhana inflasi terhadap harga obligasi pemerintah diperoleh nilai sig. sebesar $0,046<0,05$, sehingga dapat disimpulkan bahwa terdapat pengaruh inflasi terhadap harga obligasi pemerintah yang terdaftar di Bursa Efek Indonesia periode 20112017. 
Hasil pengujian simultan diketahui nilai signifikansi sebesar 0,047. Karena nilai probabilitas signifikansi sebesar $0,047<0,05$ dapat diartikan bahwa terdapat pengaruh suku bunga deposito, nilai tukar, dan inflasi secara simultan terhadap harga obligasi pemerintah yang terdaftar di Bursa Efek Indonesia periode 2011-2017.

\section{Saran}

Berdasarkan kesimpulan dari penelitian ini, maka dapat diberikan beberapa saran sehubungan dengan penelitian ini, yaitu :

Bagi investor, sebaiknya berinvestasi pada obligasi negara dengan maturity yang panjang karena obligasi negara dengan maturity yang panjang akan menghasilkan imbal hasil (yield) yang lebih besar.

Untuk investor sebagai calon pemegang obligasi sebaiknya melakukan investasi dengan membeli obligasi pemerintah karena Obligasi pemerintah merupakan instrumen yang menarik dan adanya keamanan serta bebas risiko.

Untuk agen penjualan Obligasi Negara lebih aktif dalam penjualan dan pembelian obligasi sehingga pihak pemegang obligasi dapat sewaktu-waktu lebih mudah mengadakan transaksi penjualan atau pembelian di pasar sekunder.

Untuk peneliti berikutnya, hendaknya meneliti obligasi yang lainnya yang diterbitkan pemerintah yang berupa obligasi titel indonesia (ORI).

\section{DAFTAR PUSTAKA}

Sukanto, Eman. 2009, "Pengaruh Suku Bunga Deposito, Kurs Rupiah-USD, Tingkat Inflasi, IHSG dan

Volume Transaksi Terhadap Harga Obligasi Pemerintah RI'. Jurnal Fokus Ekonomi, Vol. 4

No. 2 Desember 2009.

Azizah, Fitriatul. 2016. "Pengaruh Inflasi, Interest Rate (SBI), Jatuh Tempo dan Nilai Tukar Terhadap Harga Obligasi". Jurnal Ilmu dan Riset Manajemen, Februari 2016, Vol. 5, No. 02. STIESIA. Surabaya.

Ghozali Imam. 2011. Aplikasi Analisis Multivariate Dengan Program IBM SPSS 19. Semarang : Badan

Penerbit Universitas Diponegoro.

Bank Indonesia. Online.https://www.bi.go.id/id/moneter/inflasi/data/Default. aspx (10 November 2017). Bursa Efek Indonesia. Online. http://www.idx.co.id/id$\mathrm{id} /$ beranda/informasipasar/daftarefek/suratberharganegara.aspx. $\quad(10$ November 2017). 